EMILIA SZYMCZAK

Uniwersytet im. Adama Mickiewicza

w Poznaniu

\title{
WOMEN IN ENGEENERING - DYNAMICS OF ACCESS TO STUDIES AND PROFESSIONAL CARRER
}

\begin{abstract}
Aвstract. Szymczak Emilia, Women in Engeenering - Dynamics of Access to Studies and Professional Career [Kobiety w zawodach inżynierskich - dynamika dostępu do studiów i kariery zawodowej]. Studia Edukacyjne nr 47, 2018, Poznań 2018, pp. 173-184. Adam Mickiewicz University Press. ISSN 12336688. DOI: $10.14746 / \mathrm{se} .2018 .47 .11$

This article describes the history of women in the engineering world, the changing social and economic conditions and women's rising educational aspirations (it appears that they are interested in the traditional scientific disciplines but they also increasingly with to try typically male - form the point of view of traditional socialization - educational and then professional careers). The article presents the dynamics of the access of women to higher education through the years, including especially scientific and technical fields of study. It also presents the statistical data about the participation of women in the stereotypically male areas of education. This article provides historical examples of women, famous because of their spectacular scientific achievements.
\end{abstract}

Key words: woman, Technical University, engineering, identity, career, education

In recent years, we can observe the growth of women's participation in engineering studies. Within 10 years of the campaign (Girls to technical universities), the number of women in this type of higher education increased by nearly 9 thousands of people (from 95621 people in 2008/2009 academic year to 104039 in $2017^{1}$ ). It's especially interesting, considering the phenomena of decreasing number of students in Poland (since 2007/2008 academic year the number of all students decreased by nearly seven hundreds thousands people $\left.{ }^{2}\right)$. The biggest increase of rate of studying Polish women took place

${ }^{1}$ Kobiety na politechnikach, Raport 2007-2017, Fundacja Edukacyjna "Perspektywy”, marzec 2017, s. 3, źródło: http://www.dziewczynynapolitechniki.pl/pdfy/Raport_Kobiety_na_politechnikach_2017.pdf, [dostęp: 20.03.2018].

${ }^{2}$ Ibidem. 
at technical universities (between 2006 and 2010 women studying on technical universities constituted $9 \%$ of all studying women, whereas in the years 2015-2016 they represented almost $14 \%$ of them all ${ }^{3}$ ). We can notice that the number of women studying at technical universities rises, but it is still not big enough to speak about a total social or cultural revolution, because in 2017 women studying in this area of studies constituted $37 \%$ of all students (although the number of them is still rising ${ }^{4}$ ). For this reason, due to the information included in the report Potencjat kobiet dla branży technologiczne form these tendencies were described by the oxymoron "crawling revolution" ${ }^{.5}$ It is worth to see that even though in the numbers the growth of the participation of the women is not spectacular, the trend and dynamic of this phenomenon shows a significant change.

Nevertheless, let us go back to the beginning of the presence of women at technical schools. Before, engineering was accepted as a formal profession, women with engineering skills sought fame as inventors. One of the female inventors was Hypatia of Alexandria (a daughter of Theon of Alexandria, living at the turn of the IV/V C. E.), to whom invention of the areometer is attributed. ${ }^{6}$ Other women are: Tabitha Babbit (18-19th century), an American manufacturer of tools and inventor of the first circular saw, Sarah Guppy (1770-1852), an English woman who patented the foundations of the bridge, Rita de Moraes Sarmento (1872-1931), the first woman who in 1894 gained a title of engineer at the Technical University in Porto, which means that she could have been the first officially accepted engineer in Europe. One of the first official approved engineers in Europe was also Elisa Leonida Zamfirescu (1887-1973). In 1909 she was accepted at the Technical University of Berlin. In 1912 she graduated from the university with a degree in engineering, specializing in chemistry, probably becoming one of the first female engineers in the world.

A relevant point is the middle of 19th century, when « the storm at universities » took place; it was mainly the activity of numerous women's associations and organizations emerging in the 19th and 20th centuries. ${ }^{7}$ One of the countries, which was one of the first ones to open universities to women in the 40s in the 19th century was Switzerland. ${ }^{8}$ The new educational opportunities in Switzerland resulted in the flow of women from other countries wanting to deepen their education (including Polish and Rusian women). Taking into

\footnotetext{
${ }^{3}$ Ibidem.

${ }^{4}$ Ibidem.

${ }^{5}$ Potencjat kobiet dla branży technologicznej, Raport badawczy, Fundacja Edukacyjna „Perspektywy", Warszawa 2015, p. 8.

${ }^{6}$ Hypatia z Aleksandrii, źródło: http:/ / 4kyws.ua.edu/HYPATIA.html, [dostęp: 22.03.2018].

7 M. Bogucka, Gorsza płeć. Kobieta w dziejach Europy od antyku po wiek XXI, Warszawa 2006, p. 259-263.

8 D. Pankowska, Wychowanie a role ptciowe, Gdańsk 2005, p. 116.
} 
account the context of the analyses, it is worth to mention that the opening of universities to women didn't mean that they had access to all the fields of study. In addition, their presence in education required sometimes a permission for attending lectures or obtaining academic degrees..$^{9}$ In this manner, men could choose from study courses such as: physical science, biology, engineering, law, medicine and economics. Whereas women studied nursing, initial teaching and so called economics of household..$^{10}$ That situation, represented again a natural confirmation of a dichotomous version of the world, strongly rooted in the social consciousness essentialist paradigm, which for many years was the dominant prism of the perception of the world as well as " a social guillotine » clearly separating two realities: female and masculine. Confirmation of this dichotomy was for example the creation of an institute for future governesses in Poland in 1825, which prepared women (in terms of two-stage approach : 3 years of initial education and 4 years of vocational course) to undertake the profession of teacher in a domestic space. ${ }^{11}$

In the United States, women didn't have permission to study with men in colleges till $1832 .{ }^{12}$ One of the first female graduates from American Universities were 3 students: Mary Hosford, Mary Caroline Rudd and Elizabeth Smith Prall, who in 1841 obtained a bachelor's degree from Oberlin College..$^{13}$ Conversely, Ellen Swallow Richards was a first woman, who in 1873 received a diploma in chemistry from Massachusetts Institute of Technology. ${ }^{14}$ Whereas, in 1876 Elizabeth Bragg was the first woman to obtain a title of engineering in the United States (she obtained a diploma in civil engineering from the University of California in Berkeley). ${ }^{15}$

It is also worth to mention the period of the First and Second world War. In that time, the access of women to stereotypical male professions was almost open. The situation was integrally determined by the contemporary social and political conditions, when no one investigated and discredited the rights and opportunities attributed to the women. They could have realized successfully their professional responsibilities in the typical male domains

${ }^{9}$ M. Młodożeniec, A. Knapińska, Czy nauka wciąż ma męska płeć? Udział kobiet w nauce, Nauka, 2013, 2, p. 47.

${ }^{10}$ C.M. Renzetti, D.J. Curran, Kobiety, mężczyźni, społeczeństwo, przekł. A. Gromkowska-Melosik, Warszawa 2005, p. 143.

${ }^{11}$ S. Walczewska, Damy, rycerze i feministki: kobiecy dyskurs emancypacyjny w Polsce, Kraków 1999, p. 70-76.

${ }_{12}$ C.M. Renzetti, D.J. Curran, Kobiety, mężczyźni, p. 142.

13 OberlinHistoryFrequentlyAskedQuestions and Timeline, źródło: http://www.oberlinheritagecenter.org/researchlearn/historyfaqs, [dostęp:15.03.2018].

${ }_{14}$ J. Varrasi, PromotingWomen in Engineering, źródło: https://www.asme.org/career-education/articles/leadership-skills/promoting-women-in-engineering, [dostęp: 15.01.2018].

${ }_{15}$ Women in Engineering, http://alltogether.swe.org/2016/03/women-in-engineering-history/, [dostęp: 15.01.2018]. 
like: ironwork, shipbuilding or welding. ${ }^{16}$ An example of such woman can be Lois Graham (1925-2013), who finished Rensselaer Polytechnic Institute in 1946. She was also the first woman in the United States who obtained a doctoral degree in mechanical engineering from Illinois Institute of Technology. ${ }^{17}$

In Poland, women obtained a right of studying at universities In Lviv and Cracow in 1897 (excluding Flying University, which functioned in a clandestine manner since 1882 in Warsaw). Earlier, women accomplished their higher education abroad - for example in aforementioned Switzerland. ${ }^{18}$ Unfortunately, their return to their homeland and efforts for starting their professional careers, because of the still existing social and cultural resistance, were not always ended succesfuly. This specific situation can be illustrated by a double winner of a Nobel Prize Maria Skłodowska-Curie, who after returning from the studies done at a university in Paris (and earlier on the Flying University ${ }^{19}$ ), tried to gain employment at the Jagiellonian University and were rejected (finally, she became a professor on a elite Sorbonne in Paris ${ }^{20}$ ).

Analysing the information about the history of polytechnics functioning in Poland, it is hard to find traces concerning the participation of women. All the statistics on famous graduates and academics form mainly a list of men with only individual achievements examples of female students and graduates. The reason of this situation could have been the educational offer, which included mostly courses of study related to the domains typically concerned as male. As can be deduced, this fact represented, for many women, clear social bariers which weren't questioned because of the habitual beliefs and values. In the early years of the 20th century, a few women were accepted to engineering programs, but generally they were rare.

Janina Gibała - the first female student (auditor) at the University of Science and Technology of Cracow, which was accepted to the university in the academic year 1921/1922 and Marta Adelajda Dorota Kłyszewska (nee Suchanek) - first woman in Poland (accepted at the university a few years after as a regular student) who obtained a degree as Master engineer miner, are examples of Polish women who did not represent the socially existing norms and image of the traditional woman. They constituted examples of fighters for equal opportunities and the access to universities as well as pursuing their own interests. It is worth to mention, that along with admission of women to

${ }^{16}$ C.M. Renzetti, D.J. Curran, Kobiety, mężczyźni, p. 302.

17 Lois Graham, Engineering Education Leader, https://www.rpi.edu/about/alumni/inductees/graham.html, źródło: [dostęp: 15.01.2018].

${ }_{18}$ M. Bogucka, Gorsza płeć, p. 263.

${ }_{19}$ M. Gierczyk, D. Dobosz, Miejsce kobiet w edukacji - perspektywa historyczna, [w:] Wspótczesna kobieta. Szkice do portretu na tle przemian społeczno-kulturowych, red. D. Dobosz, K. Joniec, Katowice 2014, p. 41.

${ }^{20}$ Ibidem. 
the University of Science and technology in October 1922, a great precedent was established by the number of 8 women admitted to the first year, ${ }^{21}$ that affected the access that course of study for the future female students wanting to develop in this particular field.

A small amount of women at polytechnic schools doesn't mean that they were passive listeners of the Technological and Scientific courses of study. Frequently, their presence - because of their determination, activity and achievements - was not unnoticed. And so for example, among famous women in the United States, who undoubtedly remained in the history and had a significant influence in the developement of engineering, we can recall: Mary Anderson (who became the inventor of the windscreen wipers, even though she wasn't an Automotive engineers), Edith Clarke (who in 1918 became a first woman, who obtained a degree of an electrotechnical engineer from the Massachusetts Institute of Technology), Emily Roebling (the chief engineer while building the Brooklyn Bridge finished in 1883), Martha Coston (the author of the signaling system of flares, known as the Coston Flares, still used by United States Navy), Lillian Gilbreth (the first woman of the american association of mechanical engineers, which worked with General Electric on a technological improvement of kitchen and household appliances. What is interesting, Lillian Gilbreth was named 'a genius in the art of living', because she was perfect at combining domestic and professional responsibilities. She was a mother of 12 children so no wonder that she tried to make some housework more efficient and faster ) and Hedy Lamarr (who created a remote controlled system of communication for the american army. Sometimes, it is said that without her, there wouldn't be WI-FI nowadays. ${ }^{22}$ We cannot omit Stephanie Kowlek (American chemist of Polish descent) who in 1965 invented kevlar - a strong and resistant material - today used to produce the bulletproof vest. In 1996 she received for example National Medal of Technology). In Poland, we can include into the circle of such women out of doubt Alicja Dorabialska - a physical chemist (the first profesor of Lviv Polytechnik and afterwards Technical University of Lodz) or Sofja Kowalewska (a Russian mathematician of Polish origins, who as one of the first, In 1884, obtained a professor's degree from the Stockholm University and in 1885 she took a post of the department of Mathematics 's Dean (she was a member of The Russian Academy of Sciences). ${ }^{23}$

In the course of time, the perception of women studying the stereotypical male areas was gradually changing. Women were more and more accepted

${ }^{21}$ A. Chadaj, O pierwszej kobiecie z dyplomem magistra inżyniera górnika, Górnictwo i Geoinżynieria, 2009, 3, p. 35-36.

227 Famous Female Engineers in History, źródło: https://www.workflowmax.com/blog/ 7-famous-female-engineers-in-history, [dostęp: 22.03.2018].

${ }^{23}$ R. Swaby, Upór i przekora. 52 kobiety, które odmienity naukę i świat, Warszawa 2017. 
and tolerated, but it doesn't mean that the traditional prism of women's perception was forgotten. Unfortunately, stereotypes and traditional convictions still remained in the social consciousness. An interesting example perpetuating the traditional perception of women and showing the inappropriateness of women in science can be the appearance of a talking Barbie doll in 1992. Her first words were : "Maths class is tough, party dresses are fun. I'll always be here to help you. Do you have a crush on anyone?" 24 As we can imagine, that didn't help women to realize their aspirations in a non traditional - from the point of view of the traditional society - areas of knowledge.

Nowadays, taking into account revolutionary and radical changes for women in the area of educational and professional tendencies, along with the progression of technology in our life and the domination of neoliberal ideology. The economic factors and also the Best exploitation of human resources also had a decisive meaning for the social and economic life, in order to optimize the developement of certain regions and countries. One of the consequences of these trends can be the popularization of the directions and areas, which are crucial to the realisation of these purposes ${ }^{25}$ - i.e. areas from the STEM fields (science, technology, engineering $i$ mathematics). Consequently, in the face of the characteristic of the contemporary times: the growth of the participation of the educational aspirations, we are dealing with the growth of the participation of the women on the courses of study which were traditionally male areas, such as technical courses of study. Including women to the STEM fields is one of the elements necessary to implement this policy, which as a consequence will contribute to the growth of the number of workers corresponding to the demand of the modern reality, preparing new workforce and enlarging the extent of adopting repairing, innovative and creative activities. It would also enable women - despite the existing stereotypes and prejudices $^{26}$ - to believe their own abilities and to develop in these areas of knowledge. An example of this can be promoting some social activities whose purpose is to encourage women to take interest in these areas. The problem of the insufficient female participation in the fields of science and engineering was noticed by the European Commission, which is a initiator of the "Science:It's a Girl Thing!” program from 2012 (Polish version of this program: „Nauki ścisłe są dla dziewczyn!").27 It throws some light into the particular way in

${ }^{24}$ A. Gromkowska-Melosik, Edukacja i (nie)równość społeczna kobiet. Studium dynamiki dostępu, Kraków, 2011, p. 76.

${ }_{25}$ The Pathway Forward: Creating Gender Inclusive Leadership in Mining and Resources, Centre For Women In Politics And Public Leadership, November 2012, s. 1-2, 12, źródło: http:/ / carleton. ca/cwppl/wp-content/uploads/Women-in-Mining-2.5.pdf [dostęp: 17.03.2018].

${ }_{26}$ Potencjat Kobiet Dla Branży Technologicznej, Raport Badawczy 2015.

${ }^{27}$ Commission launches "Science: it's a girlthing!" campaign, 2012, źródło: http:/ / europa.eu/ $\mathrm{rapid} /$ press-release_MEMO-12-465_en.htm?locale=en, [dostęp:15.03.2018]. 
which the representation of women in engineering, production and building is deficient (the number of female students on the EU area is only 25,5\%), as well as in science, mathematics and computer science (where the rate of women is $40,2 \%$ of all the graduates ${ }^{28}$ ).

On the website promoting the campaign we can find information which may encourage potential female candidates to invest their interest in science. They can for example watch videos about female scientists, do the quiz, discover their favorite profession and get to know many reasons for the validity and benefits of their participation in these areas. ${ }^{29}$ Among the favorite professions, which - as the authors of the campaign say - will help change the future are: neurobiologist, biomedical engineer, geriatrician, immunologist, nutrician, agronomist, biochemist, zoologist, marine biologist, hydrologist, climatologist, environmental protection specialist, as well as many typical male domains i.e.: fuel cells specialist, geologist, renewable energy specialist, ocean engineering specialist, naval architects, electrical engineer, mechanical engineer, aerospace engineer, computer forensics specialist, software engineer, robotics engineer, data security specialist. ${ }^{30}$ These fields are renown by their important influence to, for example, health, climate protection, nutritional and social security, sustainable economic development, intelligent transport system and ecological and efficient sources of energy. Along with a good social strategy, they are another example of breaking the professional stereotypes and barriers in education practices, whose main task is to wider economic and social development. It it worth to pay attention to the fact that on the website of the program, there is an Internet browser for other iniciatives as well as formal social groups, whose purpose is to enlarge the female participation in the scientific and technical areas in european countries. Altogether, there are 75 examples of such institutions on the website. ${ }^{31}$

According to a National Science Foundation report entitled Women, Minorities, and Persons with Disabilities in Science and Engineering from 2017, the lowest rate of women we noted in engineering, computer science and physics. ${ }^{32}$ We can notice a general tendency in women of choosing more frequently their

$\begin{array}{ll}{ }^{28} & \text { Ibidem. } \\ { }^{29} & \text { Nauki ściste są dla dziewczyn. } \\ { }^{30} & \text { Ibidem. } \\ { }^{31} & \text { Ibidem. } \\ { }_{32} \text { Women, Minorities, and Persons with Disabilities in Science and Engineering, National Center }\end{array}$ for Science and Engineering Statistics Directorate for Social, Behavioral and Economic Sciences, Arlington, January 2017, s. 6-7, źródło: https:/ / www.nsf.gov/statistics/2017/nsf17310/static/ downloads/nsf17310-digest.pdf, [dostęp: 20.02.2018]; S. Elan, Study: Women encounter inequality in science $\mathcal{E}$ technology fields. Pervasive barriers restrict women's participation even in the wealthiest nations, a new study finds, źródło: https://www.elsevier.com/connect/study-women-encounter-inequality-in-science-and-technology-fields [dostęp: 20.02.2018]. 
professional career in the fields of sciences and chemical or industrial engineering than on the fields of mechanical, electrical or aerospace engineering. ${ }^{33}$ This fact is an evidence of the still remaining barriers and obstacles in the women consciousness. ${ }^{34}$ The reason for this state can be a few factors like the already mentioned stereotypes, ${ }^{35}$ a lack of sufficient number of women figures, as well a strict family environment resilient to changes. ${ }^{36}$

A confirmation of this state is a PISA report form 2015 entitled The ABC of Gender Equality in Eduaction, in which, among the reasons for the absence or insufficient women representation in the educational Fields of STEM, it is mentioned the influence of the family promoting the traditional professional choices consisting of encouraging children to realise their educational aspirations in stereotypical educational areas..$^{37}$ That's why, it is reasonable to show to the parents of girls of various ages that it is important that from the youngest age they encourage their daughters to take alternative opportunities of development and to show them all the paths to realize their own passions and develop their interests.

One of the reason for this situation is the already mentioned not sufficient number of female authority figures, i.e. women, who study for example: physics, avionics, mechatronics, mechanics, what could sufficiently encourage the young girls and make them choose this type of a professional career. The lack of authority female figure in these areas can lead to the confirmation of their lack of confidence in their own abilities and lack of belief that they can handle in these educational and after professional areas. ${ }^{38} \mathrm{I}$ think, if I would ask you right now about brilliant Polish women examples, who finished the study courses in the technical and scientific fields and contributed to the development of the scientific fields of knowledge, you could mention first of all Maria Skłodowska-Curie. But not every one knows her daughter Irena Joliot-Curie, also a Nobel prize winner, who followed her mother's career (she was a mathematician and physician and obtained a prize in the domain of the chemistry for the synthesis of the new radioactive elements). Moreover, she was an enthusiast of science - especially mathematics - what confirms

\footnotetext{
${ }^{33}$ Women, Minorities, and Persons with Disabilities in Science and Engineering, p. 6.

${ }^{34} \mathrm{~K}$. Bradley, The incorporation of women into higher education: paradoxical outcomes?, Sociology of Education 2000, 73, January, 1-18, p. 3-4.

${ }^{35}$ B. Budrowska, "Meskie”, ,kobiece”: pomiędzy stereotypem a rzeczywistościa, [w:] Problematyka kobieca - konteksty, red. M. Jeziński, M. Nowak-Paralusz, Toruń 2013, p. 263.

${ }^{36}$ D. Beede i in., Women in STEM: A Gender Gap to Innovation, August 1, 2011, s. 1, źródło; file:///C:/Users/Emilia5/Downloads/SSRN-id1964782.pdf, [dostep: 15.01.2018].

${ }_{37}$ The ABC of Gender Equality in Education: Aptitude, Behaviour, Confidence, PISA, OECD Publishing 2015, s. 138-140, źródło: http://dx.doi.org/10.1787/9789264229945-en, [dostęp: 20.02.2018].

${ }^{38}$ Ibidem, p. 141.
} 
the correspondence with her famous mother. At the age of 16 she wrote: „I'm quite good at derived functions and reversed functions are adorable. On the other hand, I'm afraid of the theory of Rolle and Thomas equation!". ${ }^{39}$

Sometimes, it happens that modern examples of success in the technical and scientific fields for women creating start-up companies or making the discoveries, are not sufficiently promoted. We cannot say about, for example, Oga Malinkiewicz, that invented the alternative manner of acquiring solar energy by exploiting perovskites. ${ }^{40}$. But for sure, it is not the only example of a successful women in the area of STEM. Therefore, if we do not popularize the achivements of the women, they won't be known among the generation of the young women, who are just discovering the world of science and many types of technology.

Nowadays, the ideology of equal chances including the opinion about equality of men and women telling that ", it is right to act against the lack of women (for example in the technical areas) by educational training and coaching activities or so called positive discrimination" replaced the constructionist conception of essentialist theory perceiving female and male social roles in a dychotomic manner. ${ }^{41}$ It's not about perceiving equal opportunities as a sign of good luck (like winning in a lottery). It is important to have the possibility to achieve the socioeconomic status by means of honest and open competition, in which the winners are the most talented and diligent individuals. We cannot deny that in contemporary societies education is a vital element of the competition to achieve an equal access to particular professions, funds and prestige. ${ }^{42}$ It opens its doors to every person interested in developing themselves in particular domains. Today, we don't have such an unambiguous divisions of male and female areas of knowledge and a stratified element are "documented achivements” as for exemple : a diploma from the university, which is evidence of acquired competences (including type and a prestige of a given university) which determine the future of the individual. ${ }^{43}$ For a woman, graduating from university on a technical course of stu-

39 D. Brian, Rodzina Curie, Warszawa 2006.

40 Polka - Olga Malinkiewicz: Olga Malinkiewicz - Polka, która może dokonać przełomu w energetyce, źródło: http://m.onet.pl/biznes/branze/energetyka-i-surowce,f92v9, [dostęp: 15.02.2018]; Zapomnijcie o grafenie, gramy na perowskity, źródło: http://www.forbes.pl/czy-olga-malinkiewicz-zbije-fortune-na-perowskitach,artykuly,183755,1,1.html, [dostęp: 15.02.2018].

41 M. Młodożeniec, A. Knapińska, Czy nauka wciąż ma męska płeć? p. 62.

42 R.J. Parelius, A.P. Parelius, The Sociology of Education, New Jersey 1987, p. 264, podaję za: A. Gromkowska-Melosik, Stratyfikacja, ruchliwość społeczna i edukacja, [w:] Problemy nierówności społecznej w teorii i praktyce edukacyjnej, red. A. Gromkowska-Melosik, T. Gmerek, Kraków 2008, p. 20.

43 Z. Melosik, Edukacja uniwersytecka i procesy stratyfikacji społecznej, Kultura - Społeczeństwo - Edukacja, 2013, 1, p. 21-22. 
dy can be an entry to a better life, a better, more prestigious job and a chance for a social promotion.

Educational and professional choices of young women are undoubtedly determined by a bigger consciousness of their own desires, determination and a consequence in realizing goals, as well as aspirations of realizing their own professional carrier. More and more frequently, they are courageous and determined to fight for their social position, a life compatible with their own values and individual choices which are not limited by stereotypical opinions. ${ }^{44} \mathrm{It}$ appears, that despite the fact that we can still talk about the bigger predisposition (existing in the social opinion) of women to fulfil certain role and professions (for example the ones related to caregiving, which is mainly relegated to women), the more important are individual talents and predispositions.

Today, women treat engineering as a developing and interesting, socially prestigious and popular domain of knowledge. The vital element of their choice is a chance to get a well paid, attractive job. In this context, a key to their success is to distance themselves from the world, to gain self confidence and an appropriate inner motivation. The work of women in the domain of engineering can be perceived as a kind of social misson, because by means of this attitude, female students want to change the world, search social and economical development, as well as execute all of their duties including their female and pro-social assets: atentiveness and empathy for other people's needs.

Nowadays, seeing a female engineer building shopping malls, roads and motorways is not uncommon. It is common that women study medicine, law or physics. Encouraging women to invest in scientific and technical interests is an excellent tendency, which gives them an opportunity to fully develop their passions. It also confirms their rising aspirations. Perhaps, in the future, women (if the actual trend is still existing and if the social stereotypes about science and the women are broken) will not be only the consumers of new devices but they will become more and more frequently inventors and producers of these devices. ${ }^{45}$

\section{BIBLIOGRAPHY}

Beede D., Julian T., Langdon D., McKittrick G., Khan B., Doms M., Women in STEM: A Gender Gap to Innovation, August 1, 2011, s. 1, źródło; file:/ / C:/Users/Emilia5/Downloads/SSRN-id1964782.pdf, [dostep: 15.01.2018].

${ }^{44}$ P. Martin, A. Barnard, The experience of women in male-dominated occupations: A constructivist grounded theory inquiry, s. 1-2, źródło: http:// www.scielo.org.za/pdf/sajip/v39n2/02.pdf, [dostęp: 15.01.2018].

${ }^{45}$ Potencjat kobiet dla branży technologicznej, Raport badawczy, p. 15. 
Bogucka M., Gorsza płeć. Kobieta w dziejach Europy od antyku po wiek XXI, Wydawnictwo Trio, Warszawa 2006.

Bradley K., The incorporation of women into higher education: paradoxical outcomes? Sociology of Education, 2000 January, 73, 1-18.

Brian D., Rodzina Curie, Wydawnictwo Amber, Warszawa 2006.

Budrowska B., „Meskie”, "kobiece”: pomiędzy stereotypem a rzeczywistościa, [w:] Problematyka kobieca - konteksty, red. M. Jeziński, M. Nowak-Paralusz, Wydawnictwo Naukowe UMK, Toruń 2013.

Chadaj A., O pierwszej kobiecie z dyplomem magistra inżyniera górnika, Górnictwo i Geoinżynieria, 2009, 3.

Commission launches "Science: it's a girlthing!" campaign, 2012, źródło: http:/ / europa.eu/ $\mathrm{rapid} /$ press-release_MEMO-12-465_en.htm?locale=en, [dostęp:15.03.2018].

Elan S., Study: Women encounter inequality in science $\mathcal{E}$ technology fields. Pervasive barriers restrict women's participation even in the wealthiest nations, a new study finds, źródło: https://www.elsevier.com/connect/study-women-encounter-inequality-in-science-and-technology-fields [dostęp: 20.02.2018].

7 Famous Female Engineers in History, źródło: https:/ / www.workflowmax.com/blog/7-famous-female-engineers-in-history, [dostęp: 22.03.2018].

Gierczyk M., Dobosz D., Miejsce kobiet w edukacji - perspektywa historyczna, [w:] Wspótczesna kobieta. Szkice do portretu na tle przemian społeczno-kulturowych, red. D. Dobosz, K. Joniec, Wydawnictwo Uniwersytetu Śląskiego, Katowice 2014.

Gromkowska-Melosik A., Stratyfikacja, ruchliwość spoteczna i edukacja, [w:] Problemy nierówności społecznej w teorii i praktyce edukacyjnej, red. A. Gromkowska-Melosik, T. Gmerek, Oficyna Wydawnicza Impuls, Kraków 2008.

Gromkowska-Melosik A., Edukacja i (nie)równość społeczna kobiet. Studium dynamiki dostępu, Oficyna Wydawnicza Impuls, Kraków 2011.

Hypatia z Aleksandrii, źródło: http:/ / 4kyws.ua.edu/HYPATIA.html, [dostęp: 22.03.2018].

Kobiety na politechnikach, Raport 2007-2017, Fundacja Edukacyjna "Perspektywy", marzec 2017, źródło: http://www.dziewczynynapolitechniki.pl/pdfy/Raport_Kobiety_na_ politechnikach_2017.pdf, [dostęp: 20.03.2018].

Lois Graham, Engineering Education Leader, https://www.rpi.edu/about/alumni/inductees/graham.html, źródło: [dostęp: 15.01.2018].

Martin P., Barnard A., The experience of women in male-dominated occupations: A constructivist grounded theory inquiry, s. 1-2, źródło: http:/ / www.scielo.org.za/pdf/sajip/v39n2/02. pdf, [dostęp: 15.01.2018].

Melosik Z., Edukacja uniwersytecka i procesy stratyfikacji społecznej, Kultura - Społeczeństwo - Edukacja, 2013, 1.

Młodożeniec M., Knapińska A., Czy nauka wciąż ma męską płeć? Udział kobiet w nauce, Nauka, 2013, 2.

Nauki ścisłe sa dla dziewczyn, źródło: http:/ / science-girl-thing.eu/pl, [dostęp: 15.02.2018].

Oberlin History Frequently Asked Questions and Timeline, źródło: http:/ / www.oberlinheritagecenter.org/researchlearn/historyfaqs, [dostęp:15.03.2018].

Olga Malinkiewicz - Polka, która może dokonać przełomu w energetyce, źródło: http:/ / m.onet. $\mathrm{pl}$ /biznes/branze/energetyka-i-surowce,f92v9, [dostęp: 15.02.2018].

Pankowska D., Wychowanie a role ptciowe, Gdańskie Wydawnictwo Psychologiczne, Gdańsk 2005.

Parelius R.J., Parelius A.P., The Sociology of Education, Prentice-Hall, New Jersey 1987.

Potencjat kobiet dla branży technologicznej, Raport badawczy, Fundacja Edukacyjna „Perspektywy", Simens, Warszawa 2015. 
Renzetti C. M., Curran D. J., Kobiety, mężczyźni, społeczeństwo, przekł. A. Gromkowska-Melosik, Wydawnictwo Naukowe PWN, Warszawa 2005.

Swaby R., Upór i przekora. 52 kobiety, które odmienity naukę i świat, Wydawnictwo Agora, Warszawa 2017.

The ABC of Gender Equality in Education: Aptitude, Behaviour, Confidence, PISA, OECD Publishing 2015, s. 138-140, źródło: http:/ / dx.doi.org/10.1787/9789264229945-en, [dostęp: 20.02.2018].

The Pathway Forward: Creating Gender Inclusive Leadership in Mining and Resources, Centre For Women In Politics And Public Leadership, November 2012, źródło: http:/ / carleton.ca/ cwppl/wp-content/uploads/Women-in-Mining-2.5.pdf [dostęp: 17.03.2018].

Varrasi J., PromotingWomen in Engineering, źródło: https://www.asme.org/career-education/articles/leadership-skills/promoting-women-in-engineering, [dostęp: 15.01.2016].

Walczewska S., Damy, rycerze i feministki: kobiecy dyskurs emancypacyjny w Polsce, Wydawnictwo eFKa, Kraków 1999.

Women in Engineering, http:/ / alltogether.swe.org/2016/03/women-in-engineering-history/, [dostęp: 15.01.2018].

Women, Minorities, and Persons with Disabilities in Science and Engineering, National Center for Science and Engineering Statistics Directorate for Social, Behavioral and Economic Sciences, Arlington, January 2017, s. 6-7, źródło: https://www.nsf.gov/statistics/2017/nsf17310/static/downloads/nsf17310-digest.pdf, [dostęp: 20.02.2018].

Zapomnijcie o grafenie, gramy na perowskity, źródło: http:/ / www.forbes.pl/czy-olga-malinkiewicz-zbije-fortune-na-perowskitach,artykuly,183755,1,1.html, [dostęp: 15.02.2018]. 